\title{
Komunikasi Pemasaran Wisata Halal Di Banyuwangi dan Gunungkidul
}

\section{Yani Tri Wijayanti}

Program Studi Ilmu Komunikasi, Fakultas Ilmu Sosial dan Humaniora UIN Sunan Kalijaga, Yogyakarta, Indonesia. Email: yani.wijayanti@uin-suka.ac.id

\section{Article Info}

Article History

Received 7 Apr 2021

Revised 19 Jul 2021

Accepted 1 Sept 2021

\section{Keywords:}

branding,

Halal Tourism, muslim friendly tourism, sharia beach tourism

\section{Kata kunci:}

branding,

muslim friendly tourism, Wisata halal, wisata pantai syariah

\begin{abstract}
The concept of Halal Tourism began to be adopted in Indonesia in 2014 and is getting stronger in Indonesia following the 2016 World Halal Tourism Award in Dubai. Several regions or districts responded to this by opening halal tourism, including Banyuwangi Regency and Gunungkidul Regency. Banyuwangi Regency launched tourist area branded as 'the first sharia beach tourism in Indonesia', namely Santen Island Beach. Meanwhile, Gunungkidul Regency is on Torohudan Beach. The research method used is a case study. The discussion includes marketing strategy and marketing communication mix, showing the implementation of halal tourism management on Santen Island Beach was successful at the beginning with very strong branding evidence, marketing communication practices have maximized marketing strategy and communication mix. At Torohudan Beach, the community prefers the principle of 'Muslim friendly tourism', and in its implementation it needs support from the local government.
\end{abstract}

Abstrak: Konsep Wisata Halal mulai diadopsi di Indonesia pada 2014,
dan semakin menguat sejak Indonesia mengikuti World Halal Tourism
Award 2016 di Dubai. Beberapa wilayah atau kabupaten menyikapi hal
tersebut dengan membuka wisata halal, di antaranya Kabupaten
Banyuwangi dan Kabupaten Gunungkidul. Kabupaten Banyuwangi me-
launching kawasan wisata yang di-branding sebagai 'wisata pantai
syariah pertama di Indonesia' yaitu pantai Pulau Santen, dan
Kabupaten Gunungkidul di pantai Torohudan. Metode penelitian yang
digunakan adalah studi kasus. Pembahasan meliputi strategi
pemasaran dan bauran komunikasi pemasaran, serta menggunakan
analisis SWOT. Hasil penelitian ini menunjukkan bahwa pelaksanaan
pengelolaan wisata halal di pantai Pulau Santen pada awal berhasilyang
dibuktikan branding yang kuat. Praktik komunikasi pemasaran telah
memaksimalkan strategi pemasaran dan bauran komunikasi. Di Pantai
Torohudan, masyarakat lebih memilih prinsip 'muslim friendly
tourism', dan dalam pelaksanaannya perlu dukungan pemerintah
setempat 


\section{PENDAHULUAN}

Jumlah penduduk muslim dunia saat ini mencapai 1,9 miliar orang atau hampir seperempat jumlah penduduk dunia. Dalam perspektif ekonomi, hal ini bisa dilihat sebagai sebuah pasar yang menjanjikan. Salah satu yang mulai melirik potensi ini adalah bisnis pariwisata. Minat terhadap wisata halal (halal tourism) mengalami pertumbuhan yang meningkat (Battour \& Ismail, 2016). Peningkatan ini seiring dengan meningkatnya wisatawan muslim dari tahun tahun (El-Gohary, 2016; Henderson, 2016).

Masalah yang sering dihadapi adalah ketersediaan fasilitas yang berkaitan dengan kepercayaan mereka. Ini memunculkan gagasan untuk mengakomodasi para pelancong muslim dengan menerapkan konsep syariah dalam bidang pariwisata, yang kemudian dikenal dengan konsep pariwisata halal (halal tourism). Haryanegara et al. (2021) mengemukakan bahwa pariwisata halal lebih memberikan ketenangan kepada wisatawan Muslim ataupun Non-Muslim karena lebih aman dan nyaman terutama bagi mereka yang membawa keluarga. Laporan COMCEC (2016) menyebutkan beberapa kriteria kebutuhan wisatawan muslim yang disebut dengan faith based needs. Kebutuhan tersebut mencakup di antaranya tersedianya: (1) makanan halal, (2) fasilitas beribadah yang layak, (3) pelayanan saat bulan Ramadhan, (4) toilet yang menyediakan air (water friendly washrooms), dan (5) fasilitas rekreasi yang memberikan privasi, dan (6) tidak ada aktivitas non halal (Battour \& Ismail, 2016).

Beberapa negara seperti Malaysia dan Turki sudah lebih dahulu bergerak untuk menangkap potensi ini. Bahkan, negara-negara 'non Muslim' seperti Thailand, Vietnam, Korea Selatan, dan Tiongkok sudah mulai bergerak aktif untuk menangkap peluang ini. Dengan penduduknya yang berjumlah 13 persen dari seluruh populasi Muslim dunia, Indonesia bisa dikatakan terlambat menyadari peluang bisnis ini.

Ada anggapan umum bahwa dengan jumlah penduduk Muslim yang banyak dan mayoritas, Indonesia pada dasarnya sudah melaksanakan konsep wisata halal, jauh sebelum konsep ini digembar-gemborkan sehingga konsep ini tidak terlalu ditanggapi. Sebagai contoh, bagi wisatawan Muslim yang berkunjung ke Indonesia, pasti tidak akan kesulitan untuk mendapatkan makanan yang berbahan baku halal dan juga dikelola secara halal. Mereka juga tidak akan kesulitan mencari tempat untuk beribadah dan sebagainya. Apalagi, pengelola sektor wisata dan segala penunjangnya juga mayoritas Muslim.

Pada 2012, Kementerian Pariwisata dan Ekonomi Kreatif mulai bergerak menyikapi meluasnya wisata halal. Dalam perkembangannya, disebut dengan sebutan 'Pariwisata Syariah', yakni 'kegiatan yang didukung oleh berbagai fasilitas dan layanan yang disediakan masyarakat, pengusaha, pemerintah, dan pemerintah daerah yang memenuhi ketentuan syariah.' Pengertian ini kemudian diperkuat dengan lahirnya Peraturan Menteri Pariwisata dan Ekonomi Kreatif Indonesia No. 2 tahun 2014 tentang Pedoman Penyelenggaraan Usaha Hotel Syariah. Syariah dalam hal ini dipahami sebagai prinsip-prinsip hukum Islam sebagaimana yang diatur fatwa dan/atau telah disetujui oleh Majelis Ulama Indonesia (MUI) (Fatkurrohman, 2017). Peraturan ini baru sebatas pada penyelenggaraan usaha hotel syariah, belum semua aspek dalam kepariwisataan. Barulah pada 2015, Kemenparekraf bersama dengan MUI, Dewan Syariah Nasional (DSN), dan Lembaga Sertifikasi Usaha (LSU) bekerjasama mengembangkan pariwisata dan mengedepankan budaya serta nilai-nilai 
agama yang kemudian dituangkan dalam Peraturan Menteri Pariwisata dan Ekonomi Kreatif (Jaelani, 2017).

Tujuan Kemenparekraf untuk membuat wisata halal di Indonesia untuk memperkaya variasi industri pariwisata dengan menebarkan daya tarik konsep halal, dan menampilkannya secara inklusif. Tujuan lainnya untuk menciptakan suatu tren baru dalam kehidupan masyarakat yang dapat diterima oleh semua kalangan. Konsep wisata halal tidak terbatas pada satu golongan saja, melainkan mencakup semua ras, etnis dan agama, yang intinya menghilangkan unsur-unsur berbahaya dan merusak pada produk atau jasa pariwisata (Pratiwi et al., 2018).

Ketika konsep pariwisata syariah atau pariwisata halal di tingkat nasional masih sebatas wacana, pada Maret 2017, dari ujung timur Pulau Jawa, tepatnya di Kabupaten Banyuwangi, diluncurkan destinasi wisata dengan konsep syariah. Tempat wisata itu adalah sebuah pantai yang berada di Pulau Santen, Kabupaten Banyuwangi, Jawa Timur. Tempat wisata ini kemudian dideklarasikan sebagai 'Wisata Pantai Syariah Pertama di Indonesia.'

Tak berselang lama, muncul kabar serupa dari Kabupaten Gunungkidul, Daerah Istimewa Yogyakarta. Gunungkidul, dalam beberapa tahun terakhir, menjadi kabupaten yang paling antusias mendorong sektor pariwisata di wilayahnya. Di Gunungkidul, bermunculan banyak tempat wisata baru yang dipromosikan melalui banyak media, terutama media sosial. Dari sekian banyak tempat wisata baru (terutama pantai) di Gunungkidul, muncul nama Pantai Torohudan, yang terletak di Desa Kanigoro, Kecamatan Saptosari yang diwacanakan menjadi destinasi wisata halal di Gunungkidul.
Sebuah produk tidak bisa dipasarkan dengan hanya mengandalkan anggapan dari penjual atau pemasarnya. Sebaliknya, harus disebutkan, dijelaskan, dan dipromosikan (Kotler \& Keller, 2011). 'Kehalalan' pariwisata di Indonesia tidak bisa hanya mengandalkan status Indonesia sebagai negara yang mayoritas berpenduduk Muslim. Pariwisata halal bukan hanya harus dikelola, tetapi juga dipromosikan. Di sinilah, komunikasi pemasaran menjadi sangat penting.

Komunikasi pemasaran (marketing communication) adalah sarana di mana perusahaan berusaha mengingatkan konsumen secara langsung maupun tidak langsung tentang produk dan merek yang dijual (Kotler \& Keller, 2011). Komunikasi pemasaran mempresentasikan "suara" perusahaan dan mereknya serta merupakan sarana di mana perusahaan dapat mengembangkan dialog dan membangun hubungan dengan konsumennya (Shimp, 2003). Bagi konsumen, komunikasi pemasaran dapat memberitahu atau memperlihatkan kepada konsumen tentang bagaimana dan mengapa suatu produk digunakan, oleh orang yang bagaimana serta di mana dan kapan?

Pemasaran sendiri tidak terlepas dari bauran pemasaran (marketing mix). Kotler \& Keller (2011) menyebut empat komponen atau elemen dalam strategi pemasaran yang disebut dengan $4 \mathrm{P}$, yakni Product, Promotion, Price, Place atau produk, promosi, harga, dan tempat. Keempat elemen ini adalah fondasi utama dalam rencana pemasaran. Dengan kata lain, empat elemen ini adalah kerangka yang akan digunakan untuk mendukung rencana pemasaran. Product merujuk pada strategi yang berkaitan dengan produk, berfungsi mendefinisikan produk, dan menentukan kepada siapa ditargetkan, dan apa manfaat yang akan ditawarkan kepada konsumen. Promotion adalah elemen 
promosi dari bauran pemasaran, dan terdiri dari komunikasi dua arah yang digunakan untuk memberi informasi, membujuk, dan mengingatkan konsumen. Price merujuk pada harga, dan harus dipertimbangkan dengan serius karena menyangkut keterjangkauan konsumen pada produk, tingkat keuntungan yang bisa diraih, serta perbandingan dengan produk pesaing. Place merujuk pada penempatan, dan sering dikenal sebagai distribusi. Ini mencakup bagaimana menyampaikan produk atau layanan kepada konsumen, atau bagaimana konsumen bisa mendapatkan produk tersebut. Penerapan komunikasi pemasaran dalam program strategi pemasaran merupakan tahapan proses atau langkah-langkah dalam memasarkan suatu produk sehingga tepat pada pasar sasaran.

Dalam pemasaran, kegiatan promosi yang efektif dan efisien dapat memasukkan bagian dari bauran komunikasi pemasaran (marketing communication mix). Menurut Kennedy dan Soemanagara (2006), bauran komunikasi pemasaran merupakan penggabungan lima model komunikasi pemasaran, yaitu advertising, sales promotion, public relations, personal selling, dan direct selling. Menurut Kotler dan Keller (2011), delapan model komunikasi utama meliputi: iklan, promosi penjualan, acara dan pengalaman, hubungan masyarakat dan publisitas, pemasaran langsung, pemasaran interaktif, pemasaran dari mulut ke mulut serta penjualan personal.

Analisis yang digunakan dalam kegiatan komunikasi pemasaran salah satunya adalah analisis SWOT. Analisis SWOT (strengths, weakness, opportunities, dan threats) adalah sebuah analisis yang didasarkan pada teknik analisis yang dibuat oleh Albert Humphrey, yang memimpin proyek riset pada Universitas Stanford pada dasawarsa 1960-an dan 1970-an dengan menggunakan data dari perusahaanperusahaan Fortune 500. SWOT adalah metode perencanaan strategis yang digunakan untuk mengevaluasi kekuatan (strengths), kelemahan (weakness), peluang (opportunities), dan ancaman (threats) dalam suatu proyek atau suatu perencanaan bisnis.

Dalam kasus ini, konsep halal yang artinya diperbolehkan dalam Bahasa Arab, tidak hanya diaplikasikan pada makanan, tapi juga termasuk pariwisata. Artinya, program pariwisata yang mengusung konsep halal harus menawarkan konsep paket wisata dan destinasi yang sangat khusus, dan dirancang untuk memenuhi kebutuhan wisatawan muslim (Chanin et al., 2015). Secara definisi, wisata halal dan wisata syariah juga masih banyak perdebatan atau belum ada sebuah konsep dan definisi yang jelas. Istilah-istilah ini juga masih tumpang tindih dengan istilah lain seperti wisata Islam (Islamic tourism), destinasi wisata ramah halal (halal friendly tourism destination), perjalanan halal (halal travel), destinasi perjalanan ramah Muslim (Muslim-friendly travel destination), dan juga gaya hidup halal (halal lifestyle) (Fatkurrohman, 2017).

Terlepas dari keragaman istilah tersebut, Carboni et al. (2014) dalam Saufi et al. (2020), menggunakan istilah 'wisata Islam' yang didefinisikan sebagai "pariwisata yang sesuai dengan Islam, melibatkan orang-orang beragama Islam yang tertarik untuk menjaga kebiasaan keagamaan pribadi mereka saat bepergian.” Battour dan Ismail (2016) menyatakan bahwa wisata halal didefinisikan sebagai semua objek atau tindakan yang diperbolehkan menurut ajaran Islam untuk digunakan atau dilibati oleh orang Islam dalam industri pariwisata.

Sebagai sebuah konsep yang baru berkembang di dunia dan baru diadopsi di Indonesia, pariwisata halal atau pariwisata 
syariah merupakan objek yang menarik diteliti dalam konteks komunikasi pemasaran. Beberapa penelitian yang berusaha mengkaji wisata halal di antaranya Fatkurrohman (2017) mengenai peran wisata syariah atau halal dalam memperkuat ekonomi, Pratiwi et al. (2018) yang meneliti peran komunikasi pemasaran dalam membangun awareness, Saufi et al. (2020) mengenai rekonseptualisasi wisata halal, dan Haryanegara et al. (2021) mengenai peran label pariwisata halal untuk menarik wisatawan. Di antara penelitian-penelitian tersebut, belum ada yang meneliti peran komunikasi pemasaran wisata halal, terutama untuk tujuan wisata pantai. Padahal, tujuan wisata ini mempunyai ciri khas jika dibandingkan dengan destinasi wisata lainnya.

Untuk mengisi kekosongan tersebut, penelitian ini mengkaji pelaksanaan pengelolaan wisata halal di pantai Pulau Santen, Kabupaten Banyuwangi, Jawa Timur, termasuk praktik komunikasi pemasaran yang dilakukannya. Penelitian ini juga akan menelisik kesiapan pemerintah desa, pengelola, dan masyarakat di Desa Kanigoro, Kecamatan Saptosari, Kabupaten Gunungkidul, DI Yogyakarta jika konsep pariwisata halal diterapkan di tempat mereka. Dengan mengkaji wisata halal di dua kasus tersebut, penelitian ini diharapkan dapat memberikan sumbangan bagi kajiankajian wisata halal yang masih belum banyak dilakukan di Indonesia, utamanya ketika diterapkan di destinasi wisata pantai.

\section{METODE}

Metode yang digunakan dalam penelitian ini adalah metode kualitatif dengan strategi studi kasus. Creswell (2016) menyatakan bahwa studi kasus ialah serangkaian kegiatan ilmiah yang dilakukan secara intensif, terinci, dan mendalam tentang suatu program, peristiwa, dan aktivitas, baik pada tingkat perorangan, sekelompok orang, lembaga, atau organisasi untuk memperoleh pengetahuan mendalam tentang peristiwa tersebut.

Subjek dalam penelitian ini adalah Dinas Kebudayaan dan Pariwisata Kabupaten Banyuwangi, Dinas Pariwisata Kabupaten Gunungkidul, Pengelola Pantai Pulau Santen Banyuwangi serta Pengelola Pantai Torohudan Gunungkidul. Objek penelitian adalah komunikasi pemasaran pariwisata halal yang dilaksanakan di dua wilayah tersebut. Pemilihan narasumber menggunakan teknik purposive sampling. Data primer dalam penelitian ini didapat dengan melakukan wawancara mendalam dengan Dinas Kebudayaan dan Pariwisata (Disbudpar) Kabupaten Banyuwangi dan Dinas Pariwisata (Dispar) Kabupaten Gunungkidul, serta para pengelola wisata pantai.

Observasi dilakukan melalui pengamatan langsung ke lokasi di pantai Pulau Santen dan Pantai Torohudan serta melakukan focus group discussion dengan pengelola wisata. Data sekunder yang digunakan berupa mencari informasi melalui buku, jurnal, dokumen resmi terkait, website serta media sosial. Analisis data dengan menggunakan model Miles dan Huberman, yaitu reduksi data, penyajian data dan penarikan kesimpulan (Sugiyono, 2016). Keabsahan data menggunakan triangulasi sumber untuk mengungkap dan menganalisis masalahmasalah yang dijadikan sebagai subjek dalam penelitian ini.

\section{HASIL DAN PEMBAHASAN}

\section{Komunikasi Pemasaran Wisata Syariah Pantai Pulau Santen}

Pulau Santen terletak di Desa Karangrejo, Kecamatan Banyuwangi, Kabupaten Banyuwangi, Jawa Timur. Di pulau ini, terdapat satu Rumah Tangga 
(RT) dengan jumlah kepala keluarga 80 Kepala Keluarga (KK). Pulau Santen ini awalnya bernama Pulau Tanjung Pakem, tapi kemudian lebih dikenal dengan Pulau Santen karena banyaknya pohon santen yang tumbuh di situ. Menurut penuturan Siwi, warga setempat, daerah itu dulunya dihuni oleh para nelayan yang menangkap ikan di Selat Bali. Awalnya, ada pemuda setempat membuat lapangan sepak bola di bagian selatan pulau. Namun, ditinggalkan sehingga rumput-rumput tumbuh subur, tetapi malah terlihat menjadi seperti savana yang menarik. Savana ini kemudian dipopulerkan oleh mahasiswa yang melakukan Kuliah Kerja Nyata (KKN) di sana.

Berdasarkan penuturan Diana, selaku Ketua RT o4 Pulau Santen, pada 2017, Bupati Banyuwangi, Abdullah Azwar Anas, datang untuk melihat savana tersebut. Saat itulah, Bupati Banyuwangi melewati Pulau Santen dan melihat potensi untuk dijadikan destinasi wisata. Bupati ingin Pulau Santen yang sebagian besar tanahnya masuk aset TNI ini bisa dimanfaatkan menjadi fasilitas publik yang bermanfaat.

Secara bertahap, Pemerintah Kabupaten Banyuwangi mulai menata kawasan tersebut. Dalam perencanaannya, seluruh pramuwisata di Pulau Santen akan mengenakan jilbab dan mengedepankan konsep Islami, di antaranya dengan memberikan salam dengan sopan. Untuk menjaga kebersihan, keindahan dan kelestarian kawasan pulau, wisatawan yang datang diwajibkan membawa kantong plastik sebagai tempat sampah makanan atau minuman yang dibawa, dan membuangnya ke tempat yang sudah disediakan. Setelah melakukan persiapan kurang lebih sepuluh hari, Pulau Santen akhirnya resmi dibuka sebagai destinasi wisata halal. Peresmiannya pun dilaksanakan secara meriah pada 2 Maret 2017 pukul 07.00 WIB, tepat bersamaan dengan kedatangan Raja Salman ke Pulau Bali yang letaknya ada di hadapan Pulau Santen. Pantai Pulau Santen pun viral di media dengan branding Pantai Syariah dan mulai ramai didatangi pengunjung, ada 2000 pengunjung yang datang pada liburan akhir pekan, 800 karcis habis (Albab, 2017).

Disbudpar memaparkan ada dua tujuan utama mempromosikan pantai Pulau Santen sebagai tempat wisata halal. Pertama, mengangkat potensi pantai Pulau Santen karena pemandangannya (view) sangat bagus, tetapi tidak terurus. Kedua, meningkatkan kesejahteraan masyarakat setempat yang sehari-hari bekerja sebagai nelayan. Setelah pembukaan, masyarakat merasakan dampak positif terutama bagi perekonomian mereka. Banyak peluang usaha yang bisa dimanfaatkan oleh masyarakat setempat seperti menjual makanan, menjadi tukang ojek, tenaga kebersihan, dan lain-lain. Dari usaha tersebut, mereka bisa mencukupi kehidupan sehari-hari, dan tidak hanya mengandalkan penghasilan sebagai nelayan saja. Meskipun demikian, tempat wisata yang berani mem-branding dirinya sebagai Pantai Syariah pertama di Indonesia itu tidak berumur panjang. Persoalannya bukan dari konsep syariah atau branding wisata halal yang disebutkannya, tetapi lebih karena persoalan administrasi dan pengelolaan. Tanah yang dijadikan tempat wisata tersebut merupakan lahan milik Kodim Banyuwangi. Ketika dijadikan destinasi wisata, pulau dikelola oleh Disbudpar. Masalah muncul ketika lahan tersebut diambil alih kembali oleh Kodim, sebagaimana dikemukakan Siwi, "Tapi setelah berjalan sekian bulan, entah kenapa pengelolaannya diambil alih kembali oleh pihak Kodim.” (Siwi, Wawancara, 23 Agustus 2019). 
Sementara menurut Diana, banyak wisatawan keberatan dengan harga tiket sebesar Rp. 3.000,- yang dikenakan kepada pengunjung. Masalah lainnya, banyak masyarakat yang mempermasalahkan pemisahan area perempuan dan laki-laki di Pantai Santen. Menurutnya, banyak yang memprotes hingga ramai di media sosial. Permasalahan mengenai pelaksanaan wisata syariah di Pulau Santen ini juga diakui oleh pihak Disbudpar Banyuwangi. Setelah berjalan kurang dari dua tahun, akhirnya berhenti (Diana, Wawancara, 23 Agustus 2019).

Dilihat dari perspektif pemasaran, pelaksanaan penyelenggaraan wisata syariah atau wisata halal di pantai Pulau Santen Banyuwangi dapat dianalisis dengan menggunakan Analisis SWOT (strengths, weakness, opportunity, threats) sebagai berikut.

\section{Product}

Strengths. Dari sisi ini, kelebihan dari Pulau Santen adalah dari sisi branding syariah yang digunakannya. Secara tidak langsung, memberi citra yang lebih baik dari produknya. Selain itu, sisi packaging produk juga menjadi salah satu kekuatannya. Packaging produk yang dilakukan di pantai Pulau Santen adalah dengan memberi citra enak dipandang dan dijadikan objek foto (instagramable). Weakness. Salah satu kelemahannya adalah atraksi wisata yang ditawarkan. Selain hanya pemandangan pantai, tidak ada kegiatan lain yang bisa dinikmati pengunjung. Opportunities. Dengan branding sebagai 'wisata pantai syariah pertama', peluang pengembangan wisata halal di Pantai Pulau Santen sebetulnya sangat terbuka. Peluang ini dapat dilihat dari adanya segmentasi pasar yang khas; selain bagi masyarakat umum, juga bagi mereka yang memang menginginkan adanya jenis wisata seperti ini. Threats.
Ancaman utama bagi wisata Pantai Pantai Pulau Santen dari sisi produk adalah kondisi pulau yang berada di muara sungai yang melintasi kota. Ini sangat rentan menjadi lokasi sampah kiriman dari kota, apalagi pada musim penghujan.

\section{Promotion}

Strengths. Branding sebagai 'wisata pantai syariah pertama di Indonesia' adalah salah satu kekuatan dari sisi promosi pantai Pulau Santen. Weakness. Meski branding sebagai 'wisata pantai syariah pertama di Indonesia' adalah salah satu kekuatan, hal ini juga bisa berbalik menjadi salah satu kelemahan apabila pelaksanaan di lapangan tidak sesuai yang dijanjikan. Opportunities. Dengan branding sebagai 'wisata pantai syariah pertama', peluang pengembangan wisata halal di pantai Pulau Santen sebetulnya sangat terbuka. Peluang ini dapat dilihat dari adanya segmentasi pasar yang khas; selain bagi masyarakat umum, juga bagi mereka yang memang menginginkan adanya jenis wisata seperti ini. Threats. Branding syariah juga ternyata menimbulkan polemik di kalangan masyarakat lain akibat munculnya isu 'arabisasi' yang kontraproduktif dengan citra syariah yang ditawarkannya.

\section{Price}

Strengths. Harga tiket masuk ke Pantai Pulau Santen cukup terjangkau, yakni Rp. 3.000. Apalagi saat pelaksanaan wisata syariah, pengunjung yang masuk juga diberikan sebotol air mineral gratis. Weakness. Ketiadaan atraksi wisata lainnya (baik yang konvensional maupun yang sesuai dengan citra syariah yang dikembangkannya) bisa menjadi kelemahan di pantai Pulau Santen. Opportunities. Dari sisi harga, tiket masuk yang murah dengan tambahan air mineral untuk pengunjung, ada kesempatan bagi pantai Pulau Santen untuk bisa menarik 
lebih banyak lagi pengunjung. Threats. Penetapan tiket yang terlalu rendah tadi, di satu sisi juga menjadi ancaman bagi pelaksanaan wisata di pantai Pulau Santen ini.

\section{Place}

Strengths. Salah satu kekuatan yang dimiliki oleh pantai Pulau Santen dalam hal penempatan adalah lokasinya yang tak jauh dari pusat Kota Banyuwangi. Dengan demikian, akses pengunjung menjadi mudah. Weakness. Dari sisi penempatan atau lokasi, akses jalan yang sempit menuju lokasi bisa menjadi kelemahan apalagi jika pengunjung datang dalam rombongan besar dengan menggunakan kendaraan besar seperti bus. Lokasi pantainya juga sempit sehingga tidak memungkinkan untuk menampung pengunjung dalam jumlah besar secara bersamaan. Opportunities. Dengan lokasi yang tidak terlalu jauh dari pusat kota, Pantai Pulau Santen sebetulnya memiliki peluang untuk dijadikan sebagai tempat wisata 'tambahan' atau bukan sebagai tempat tujuan utama. Hal ini didukung dengan banyaknya penginapan yang ada letaknya tak jauh dari Pantai Pulau Santen. Threats. Ancaman utama adalah soal kepemilikan lahan yang merupakan milik pihak ketiga, dalam hal ini TNI AD.

\section{Komunikasi pemasaran yang dilakukan dalam mempromosikan} pariwisata pantai syariah di Pantai Pulau Santen yang dilakukan oleh Dinas Kebudayaan dan Pariwisata Banyuwangi dan Pengelola Pantai, yaitu dengan 1) Iklan melalui baliho, website dan majalah; 2) Promosi melalui percobaan tiket masuk gratis; 3) Melakukan berbagai acara; 4) Membangun kerjasama stakeholders yang terlibat, publisitas di awal cukup baik dengan gencarnya pemberitaan di media online hingga branding wisata pantai syariah ini menjadi viral. Namun akhirnya, pemberitaan berjalan kurang baik dikarenakan adanya persepsi publik terkait 'arabisasi'; 5) Pemasaran interaktif dilakukan dengan memaksimalkan media sosial dan website; 6) Komunikasi dari mulut ke mulut sehingga membuat masyarakat tertarik untuk berkunjung.

Bauran komunikasi pemasaran dalam rangka promosi Pantai Pulau Santen pada akhirnya tidak berjalan dengan baik dan berkelanjutan karena masalah internal dalam pengelolaannya sehingga tidak berkelanjutan atau gagal di tengah jalan. Akibatnya, kondisinya sepi dan terkesan tidak terurus.

\section{Kesiapan Pariwisata Halal Pantai Torohudan}

Destinasi Pantai Torohudan sebagai wisata halal ternyata masih berupa rencana yang datangnya dari atas (top down) atau bukan aspirasi dari bawah (masyarakat). Ini sama dengan yang terjadi di pantai Pulau Santen Banyuwangi. Bedanya, jika di pantai Pulau Santen jarak antara ide dengan eksekusi tidak terlalu jauh sehingga rencana itu sempat diwujudkan hingga berjalan selama kurang lebih dua tahun, sementara di pantai Torohudan, wacana Dinas Pariwisata Gunungkidul sudah sampai ke telinga masyarakat, tetapi tidak pernah dieksekusi atau ditindaklanjuti secara nyata. Menurut Kepala Desa Kanigoro, Suroso, masyarakat di sekitar Pantai Torohudan sebetulnya tidak terlalu mempermasalahkan konsep wisata apa yang akan diterapkan oleh pemerintah. Sebaliknya, selama hal itu dianggap memberi keuntungan bagi warga sekitar.

Terlepas dari jadi tidaknya konsep wisata halal di pantai Torohudan, analisis SWOT bisa dilakukan sebagai berikut.

\section{Product}

Strengths. Kelebihan dari sisi produk adalah kondisi alamnya yang memang 
potensial. Pantai Torohudan tersembunyi di balik ladang dan perkebunan warga. Branding halal jika dilaksanakan akan menjadi semacam pembeda pantai Torohudan dari pantai lain di Gunungkidul yang jika dilihat dari sisi topografi atau pemandangan alam, umumnya memiliki kemiripan atau kesamaan. Weakness. Sejauh ini, kelemahan utama pantai Torohudan dilihat dari sisi produk adalah akses dan fasilitas yang masih sangat terbatas. Opportunities. Menjadikan pantai Torohudan sebagai destinasi wisata halal menjanjikan peluang besar. Pertama, dari sisi persaingan, branding seperti yang dilakukan oleh pantai Pulau Santen Banyuwangi terbukti bisa menarik minat pengunjung. Padahal dari sisi produk, apa yang ditawarkan oleh Pantai Torohudan jauh lebih menarik. Ini belum termasuk potensi aktivitas wisata yang bisa dilakukan pengunjung yang lebih beragam, misalnya memancing, berkemah, dan lain sebagainya. Threats. Nyaris tak ada ancaman yang berarti jika pantai Torohudan dikembangkan menjadi destinasi wisata halal.

\section{Promotion}

Strengths. Salah satu kekuatan yang dimiliki pantai Torohudan jika dijadikan sebagai destinasi wisata halal adalah dukungan dari Dispar Gunungkidul yang sangat besar, juga dari Dispar DIY. Weakness. Kelemahan utama justru berada dalam persepsi masyarakat sendiri mengenai konsep wisata halal. Opportunities. Belum adanya tempat wisata di DIY umumnya, dan Gunungkidul khususnya yang menerapkan konsep wisata halal atau mem-branding sebagai tempat wisata halal. Ini merupakan kesempatan yang besar. Threats. Dilihat dari sisi ancaman, juga serupa dengan yang menjadi kelemahan, yakni mengenai pemahaman masyarakat yang belum baik mengenai konsep wisata halal ataupun wisata syariah.

\section{Price}

Strengths. Harga tiket masuk ke pantaipantai yang ada di Desa Kanigoro adalah sebesar Rp. 5.00o untuk semua pantai, baik itu pantai Ngobaran, Ngrenehan, Nguyahan, Midodaren, termasuk juga untuk pantai Torohudan dan pantai lain yang belum dikembangkan. Weakness. Meski terlihat murah, Rp. 5000 all in atau bisa mengunjungi semua lokasi, tapi angka ini bisa dirasakan cukup mahal karena pengunjung tidak dapat menikmati semua pantai dengan nyaman karena jaraknya berjauhan dan akses yang masih cukup sulit. Opportunities. Jika atraksi wisata di masing-masing pantai bisa ditambah atau masing-masing pantai bisa menawarkan kekhasan masing-masing akan memperbesar kesempatan. Threats. Penetapan tiket masuk yang terlalu rendah, juga menjadi ancaman. Hal ini akan menyulitkan bagi pengembangan lokasi wisatanya jika pemasukannya masih kecil dan sebagian masuk ke kas desa untuk pembangunan sarana desa lainnya, bukan hanya pembangunan tempat wisata.

\section{Place}

Strengths. Salah satu kekuatan yang dimiliki oleh pantai Torohudan dalam hal penempatan adalah lokasinya yang tidak terlalu jauh dari jalur selatan yang menghubungkan pantai-pantai di wilayah selatan Gunungkidul. Weakness. Salah satu kelemahan yang paling besar adalah akses menuju lokasi yang masih sulit. Opportunities. Dari sisi lokasi, peluang terbesar adalah adanya proyek pengembangan jalur selatan Gunungkidul yang memang diproyeksikan sebagai jalur wisata. Desa Kanigoro sendiri dilalui oleh jalur ini. Threats. Sebagaimana disebutkan oleh Purnomo dari Dispar Gunungkidul, ancaman yang perlu dihadapi dari sisi 
lokasi adalah pindahnya bandara internasional Yogyakarta yang tadinya dari Adisucipto ke bandara baru di Kulonprogo. Ini membuat wisatawan terutama dari luar, semakin jauh dari Gunungkidul.

\section{Perbandingan Komunikasi \\ Pemasaran di Pantai Pulau Santen dan Pantai Torohudan}

Dari dua kasus wisata halal yang dipaparkan dalam penelitian, ada beberapa hal yang dapat diperbandingkan, yakni strategi pemasaran, aspek pendukung, dan aspek wisata syariah.

\section{Aspek Strategi Pemasaran}

Dari sisi product, pantai Pulau Santen Banyuwangi sebetulnya tidak memiliki keistimewaan yang luar biasa. Sebaliknya, pantai Torohudan lebih potensial. Dari sisi promotion, keduanya memiliki kelemahan karena promosi yang dilakukan masih mengandalkan promosi yang dilakukan oleh pemerintah daerah masing-masing, sementara promosi swadaya yang dilakukan masih bersifat sporadis atau belum terkoordinasi sehingga sama-sama belum maksimal. Branding sebagai 'tempat wisata syariah pertama di Indonesia' yang digunakan di pantai Pulau Santen terbukti cukup kuat. Jejak digital mengenai promosi ini masih tersisa di internet. Ketika mencari dengan kata kunci 'wisata halal' nama pantai Pulau Santen masih muncul di atas, bahkan ketika program ini sudah tidak berjalan lagi. Dari sisi price, keduanya memiliki keunggulan masing-masing, tapi pantai Torohudan memiliki kelebihan lain dari sisi keragaman atraksi wisata yang potensial untuk dikembangkan sehingga harga (tiket masuk) yang ditawarkan memberi nilai lebih bagi pengunjung. Sementara dari sisi place, dalam hal ini lokasi, dua-duanya memiliki keunggulan dalam hal kedekatan dengan lokasi wisata utama. Pantai Pulau Santen dekat dengan jalur wisata ke Bali, sementara pantai Torohudan dekat dengan Yogyakarta.

\section{Aspek Pendukung}

Dalam kasus pantai Pulau Santen Banyuwangi, aspek krusial dalam pelaksanaan wisata syariah seperti yang dipublikasikan justru terletak dari persoalan kepemilikan lahan yang dimiliki oleh pihak ketiga, yakni TNI Angkatan Darat. Masalah kepemilikan inilah yang menjadi penyebab berhentinya pelaksanaan wisata syariah di pantai Pulau Santen. Sementara jika jadi dikembangkan, masalah seperti ini tidak akan muncul di pantai Torohudan karena lokasi yang akan dijadikan tempat wisata adalah tanah desa dan sebagian milik warga.

\section{Aspek Wisata Syariah}

Pengalaman pantai Pulau Santen menjalankan konsep wisata syariah (meskipun keburu berhenti di tengah jalan) menunjukkan bahwa, dari sisi pemasaran, branding wisata syariah atau wisata halal ini bisa 'dijual.' Ini terlepas apakah memang ada kebutuhan masyarakat mengenai wisata syariah atau wisata halal atau hanya sekadar efek viral di media sosial yang saat ini diakui sering mendorong terjadinya lonjakan ke sebuah tempat wisata terutama yang menjanjikan nilai kebaruan. Tentu saja, perlu dilakukan penelitian lebih lanjut apalagi ketika konsep wisata ini tidak berlanjut di pantai Pulau Santen karena masalah kepemilikan. Terlepas dari hal itu, kasus pantai Pulau Santen membuktikan bahwa wisata syariah atau wisata halal adalah sebuah konsep yang menarik perhatian masyarakat.

Terkait persepsi masyarakat tentang wisata syariah atau wisata halal, di pantai Pulau Santen, persepsi masyarakat masih cenderung negatif. Seperti disampaikan oleh warga Pulau Santen sendiri dan juga 
didukung oleh penjelasan dari Disbudpar Banyuwangi, masih ada persepsi yang salah mengenai konsep wisata ini. Istilah 'arabisasi' akibat pemisahan pengunjung perempuan dan laki-laki di pantai Pulau Santen adalah bukti bahwa konsep ini masih disalahartikan. Di kalangan para pelaku wisata di Desa Kanigoro sendiri, termasuk di Dispar Gunungkidul, keraguan akan penggunaan istilah ini juga masih ada. Dari hasil FGD, terlihat bahwa ada ketakutan pengelola wisata di Desa Kanigoro akan kehilangan pengunjung jika istilah itu digunakan. Istilah 'wisata syariah' adalah yang paling 'ditakuti' dan istilah 'wisata halal' meski bisa diterima masih diragukan penggunaannya. Ini mendorong Dispar Gunungkidul berpikir untuk menggunakan istilah lain, yakni 'Muslim Friendly Tourism' untuk tetap membidik pasar pengunjung dari kawasan negara-negara Muslim. Masyarakat di Desa Kanigoro sendiri menganggap penggunaan istilah apapun sementara belum diperlukan, selama prinsip wisata yang ramah kepada wisatawan Muslim sudah dijalankan dengan banyaknya fasilitas penunjang, misalnya, tempat ibadah, makanan halal, kamar mandi terpisah, dan sebagainya. Hal ini sejalan dengan pendapat Pratiwi et al. (2018) yang menyatakan bahwa wisata halal merupakan bagian dari industri pariwisata yang ditujukan untuk wisatawan muslim. Wisata halal mesti mempertimbangkan hukum Islam dalam menentukan produk dan layanan wisata. Ferdiansyah et al. (2020) juga berpendapat bahwa pengembangan wisata halal di Indonesia dapat menerapkan unsur pengembangan destinasi yang ramah keluarga, layanan, dan fasilitas yang ramah muslim, dan sadar halal. Jika hal ini dikerjakan, maka apapun nama yang digunakan akan tetap memuat semangat wisata halal atau syariah.

\section{KESIMPULAN}

Berdasarkan pembahasan dapat disimpulkan bahwa pelaksanaan pengelolaan wisata halal di pantai Pulau Santen di awal berjalan dengan baik, mampu membentuk branding sebagai tempat wisata syariah pertama di Indonesia, bahkan sempat viral di media sosial. Dengan mengusung konsep wisata syariah, membuat masyarakat tertarik dan penasaran. Ini mampu meningkatkan kunjungan wisata di pantai Pulau Santen. Peningkatan kunjungan wisata tersebut menjadi hal yang menguntungkan secara ekonomi bagi pemerintah daerah dan masyarakat sebagai pelaku wisata. Penggunaan konsep komunikasi pemasaran dengan memanfaatkan empat komponen strategi pemasaran yaitu product, promotion, price, dan place menjadi salah satu indikator keberhasilan konsep wisata di pantai Pulau Santen. Sayangnya, hal ini tidak berlangsung lama dikarenakan permasalahan dalam pengelolaannya antara Disbudpar, Kodim dan masyarakat setempat sehingga pengelolaan wisata pantai halal ini berhenti begitu saja. Untuk pelaksanaan promosi yaitu implementasi kegiatan komunikasi pemasaran, Disbudpar dan pengelola di awal launching pantai sudah memaksimalkan bauran komunikasi pemasaran dengan baik.

Terkait persiapan konsep pariwisata halal di Pantai Torohudan, pantai ini mempunyai potensi untuk bisa dikembangkan menjadi destinasi wisata halal, dan menjanjikan peluang besar, terlebih adanya dukungan dari pemerintah dalam hal ini Dispar Kabupaten Gunungkidul. Tentang kesiapan konsep wisata halal, masyarakat dan Dispar sepakat lebih memilih prinsip wisata yang ramah kepada wisatawan Muslim, dengan memberikan fasilitas penunjang, misalnya, tempat ibadah, makanan halal, kamar mandi terpisah, dan sebagainya. Oleh 
karena itu, mempromosikan fasilitas tersebut lebih dipilih oleh mereka ketimbang istilah 'syariah' ataupun 'halal'. Penulis memberikan saran atau masukan dari beberapa aspek. Dari aspek komunikasi pemasaran, yang paling penting adalah upaya pelibatan masyarakat dalam kegiatan promosi swadaya termasuk berbagai sarana dan prasarana penunjangnya, terutama memaksimalkan media sosial. Dari aspek wisata halal, dengan mengambil contoh di pantai Pulau Santen dan Pantai Torohudan, persoalan utama dalam pengembangan wisata syariah atau wisata halal di Indonesia adalah pemahaman mengenai konsep-konsep tersebut. Perdebatan mengenai istilah, baik wisata syariah, wisata halal, maupun wisata ramah muslim, harus segera diselesaikan dengan adanya definisi yang jelas dan juga standar pelaksanaan yang jelas. Definisi dan sosialisasi mengenai konsep ini juga harus diarahkan kepada masyarakat umum, sehingga konsep yang memiliki tujuan baik dan tidak terlalu sulit diaplikasikan di Indonesia ini tidak terlanjur mendapatkan citra yang buruk atau dipahami secara salah. Untuk itu, Kemenparekraf harus segera menggandeng lembaga terkait seperti Majelis Ulama Indonesia untuk segera merumuskan definisi, mematangkan konsep, membuat standar, dan juga mensosialisasikannya kepada masyarakat.

\section{UCAPAN TERIMA KASIH}

Penulis mengucapkan terima kasih kepada Lembaga Penelitian dan Pengabdian Masyarakat (LPPM) UIN Sunan Kalijaga yang telah memberikan dana hibah penelitian pada kluster Terapan Nasional Tahun 2019, Fatimah Arum Utari dan Ghulam Anif Yulianto yang sudah membantu dalam pelaksanaan penelitian ini, serta berbagai pihak yang telah membantu penulis ketika melakukan penelitian ini baik di Kabupaten Banyuwangi maupun Kabupaten Gunungkidul 


\section{DAFTAR PUSTAKA}

Albab, M. U. (2017, March). Ribuan pengunjung mulai padati wisata syariah beach.

Battour, M., \& Ismail, M. N. (2016). Halal tourism: Concepts, practises, challenges, and future. In Tourism Management Perspectives (Vol. 19, pp. 150-154).

https://doi.org/10.1016/j.tmp.2015.1 2.008

Chanin, O., Sriprasert, P., Rahman, H. A., \& Don, M. S. (2015). Guidelines on halal tourism management in the andaman sea coast of Thailand. Journal of Economics, Business and Management, 3(8), 791-794. https://doi.org/10.7763/joebm.2015. v3.287

COMCEC. (2016). Muslim friendly tourism: Understanding the demand and supply sides in the OIC member countries. COMCEC Coordination Office, August, 1-112.

Creswell, J. W. (2016). Research design (Pendekatan metode kualitatif, kuantitatif, dan campuran). In Terjemahan Bahasa Indonesia (Issue 150). Pustaka Pelajar.

El-Gohary, H. (2016). Halal tourism, is it really halal? In Tourism Management Perspectives (Vol. 19, pp. 124-130). https://doi.org/10.1016/j.tmp.2015.1 2.013

Fatkurrohman, F. (2017). Developing Yogyakarta's halal tourism potential for strengthening islamic economy in Indonesia. Afkaruna: Indonesian Interdisciplinary Journal of Islamic Studies, 13(1).

https://doi.org/10.18196/aiijis.2017. 0065.1-16
Ferdiansyah, H., Endyana, C., Rachmat, H., \& Khadijah, U. L. S. (2020). Pengembangan pariwisata halal di Indonesia melalui konsep smart tourism. Tornare: Journal of Sustainable Tourism Research, 2(1), 30-34. https://doi.org/10.24198/tornare.v2i 1.25831

Haryanegara, M. E. A., Akbar, M. A. I., \& Novianti, E. (2021). Peran label pariwisata halal sebagai daya tarik wisata budaya di Lombok, Nusa Tenggara Barat. Tornare: Journal of Sustainable Tourism Research, 3(1), 35-39.

https://doi.org/https://doi.org/10.24 198/tornare.v3i1.29839

Henderson, J. C. (2016). Halal food, certification, and halal tourism: Insights from Malaysia and Singapore. In Tourism Management Perspectives (Vol. 19, pp. 160-164). https://doi.org/10.1016/j.tmp.2015.1 2.006

Jaelani, A. (2017). Industri wisata halal di Indonesia: Potenssi dan pospek (Halal tourism industry in Indonesia: Potential and prospects). Munich Personal RePEc Archive Halal, 76237.

Kennedy, J. E., \& Soemanagara, R. D. (2006). Marketing communication: Taktik dan strategi. PT Buana Ilmu Populer.

Kotler, P., \& Keller, K. L. (2011). Manajemen pemasaran jilid 2 (13th ed.). Erlangga.

Pratiwi, S. R., Dida, S., \& Sjafirah, N. A. (2018). Strategi komunikasi dalam membangun awareness wisata halal di Kota Bandung. Jurnal Kajian Komunikasi, 6(1), 78. https://doi.org/10.24198/jkk.v6i1.12 985 
Saufi, A., Mulyono, L. E. H., Apriani, B. L., Rojabi, S. H., Kholid, I., Jayadi, H., \& Putri M, E. D. (2020). Pariwisata halal: Perlukah rekonseptualisasi? JMM UNRAM - Jurnal Magister Manajemen Universitas Mataram, 9(3), 305-314.

https://doi.org/10.29303/jmm.v9i3. 580
Shimp, T. A. (2003). Periklanan promosi: Aspek tambahan komunikasi pemasaran terpadu (N. Mahanani (ed.); 5th ed., Vol. 1). Erlangga.

Sugiyono. (2016). Metode penelitian kualitatif, kuantitatif, dan R\&D. In Metode Penelitian dan Pengembangan Pendekatan Kualitatif, Kuantitatif, dan R\&D. Alfabeta. 